\title{
The Municipal Retail Market in the Modernization of the Structure for Distributing Daily Necessities in Japan's Cities
}

\author{
From the End of the Nineteenth \\ Century until World War II \\ Makoto Hirota \\ Faculty of Economics, Kobe Gakuin University
}

\begin{abstract}
S IS ALREADY generally known, Japan's economic growth prior to World War II was very spectacular, and the progress made 1 by some of the modern large enterprises was nothing short of amazing. Such progress in the economy and in enterprise activities did not bring about an expansion of the domestic individual consumption market proportionate to the economic growth. Two reasons for this were the fact that the large enterprises were producing mainly intermediate investment goods (cotton yarn, coal, steel, ships, etc.), and the fact that most of the products were destined for overseas markets, not only those produced by large enterprises but also those produced by small and medium-sized enterprises. Consequently, in prewar Japan there existed no mass production system for consumer goods such as was found in the countries of the West. Nor was there firmly in place a distribution system that was adaptable to a mass production system, even though there were exceptions-the systematiza-
\end{abstract}


tion of sales structures by a small percentage of pioneering manufacturers, for example, or the growth of department stores.

Still, despite limitations of the sort mentioned above, the high degree of growth of the economy and the advance of large enterprises led to rapid urbanization (the concentration of the population in the cities), and the demand for daily necessities such as rice, perishable foods, alcoholic beverages, and seasonings (shōyu, miso) increased sharply. The distribution structures and transaction methods of that time were not, however, able to cope with such changes, and the sudden steep rises in the prices of daily necessities that resulted became a social problem. Nvertheless, voluntary moves toward distribution modernization on the part of private enterprise involved in this area were few and far between. It was the government (on both the central and local levels) that from around 1910 onward filled the vacuum and, through a variety of policies, took the lead in efforts at modernizing distribution.

The primary reason why the government took the lead in developing policies to modernize distribution structures in order to eliminate the steep rises in the prices of daily necessities was maintenance of public order in the cities. Still, another reason that is of greater interest from the viewpoint of research into business history and the history of distribution is the perception that gained wide currency among powerful figures in the industrial world and officials in both the central and local governments in the period immediately after World War I, namely, that "steep rises in the prices of daily necessities will lead to rises in wages and lower the competitiveness of the manufacturers mainly engaged in the export industry." In other words, the industrial world and the government of that time were convinced that, in order for Japan's economy and Japan's enterprise to maintain their smooth development, it was necessary to ensure a stable supply of inexpensive daily necessities in the cities, which were the key centers of economic activity. ${ }^{1}$

In this paper, I propose to limit my discussion of the modernization of the distribution of daily necessities in Japan to the measures taken in connection with the modernization of the retail sector.

\footnotetext{
' Masami Harada, Kindai Nihon shijōshi no kenkyū [A study of the history of modern Japan's markets] (Soshiete, 1991), pp. 111-16.
} 


\section{THE GOYŌKIKI AND SALE-ON-CREDIT SALES SCHEME}

In Japanese cities around the end of the nineteenth century and the beginning of the twentieth century, most daily necessities, particularly foodstuffs, were being distributed by means of small, individually-owned shops operating in close proximity to the places where the customers lived. Since in such a situation the seller and the buyer were practically neighbors, the principal method of selling goods was that of goyo $k i$ $k i$, in which the retailer visited the consumer's home, took an order, and delivered the goods to the home, with the sale being on credit and payment to be made later, usually at a fixed time such as the end of the month. Because the retailers were able to learn in the course of goyokiki dealings a good deal about the living conditions of their customers, it was possible for them to grant credit in the secure knowledge that bills would be paid. And in this way the retailers were also able to keep their own living stable and secure.

For the city-dwelling customers (who were mainly middle or lower class), on the other hand, buying their daily necessities under the goyöki$k i$ and credit sale system was attended by possibilities for abuse; for one thing, since the relation between customer and seller was fixed and there was no competition, and since the bad debt risk involved in sales on credit and the personnel costs involved in the goyokiki routine were added into the retail prices, they were forced to buy goods at high prices. Nevertheless, at times when their day-to-day living was subject to temporary crisis (brought about by such things as skyrocketing prices, unemployment, or cuts to wages), they had no other choice but to buy on credit until they could ride out the crisis, and thus it was not easy to cut their reliance upon the sale-on-credit scheme.

In order for the reader to have a more concrete understanding of the relationship between the retailers of daily necessities and city dwellers, I would like to present some materials that document the situation in which daily necessities were purchased in cities from the end of the nineteenth century to the beginning of the twentieth century.

First let us look at what a person active in the labor movement of that period, Fusatarō Takano, had to say about conditions in Tokyo. According to an account given by Takano in July 1897, the great majority of Japanese laborers "owed large amounts of money to shop- 
keepers and were regular customers of pawnshops and moneylenders.... If they were fortunate enough to earn extra money....they could repay the money they owed," but when this proved to be an impossibility, "the laborers who were particularly hard-pressed...fled at night, went into hiding in parts of the town where they would not be noticed, and hid from the eyes of their creditors."

Thus laborers in the city of Tokyo at the end of the nineteenth century were trying to make up for insufficient income caused by fluctuations in economic conditions by borrowing directly from whomever they could and at the same time by relying on borrowing money from the sellers of daily necessities (by buying, that is, daily necessities on the sale-on-credit scheme), and it was no easy matter to escape from such conditions.

In order to liberate Tokyo laborers from such conditions Takano took as his model the Rochdale Pioneers Society of England, and he spared no efforts in trying to organize and establish a consumers' cooperative society of laborers. According to what he said in June 1897, however, the principle adopted by the cooperative society he organized was that "Members who made purchases in the co-op shop are to pay for them on the 15th and 30th of each month."3

In other words, Takano and his fellow organizers did not adopt the cash purchase method that "the Rochdale Pioneers Society and most of their successors valued so highly. . . and that was a big factor in the Society's success," even though the Rochdale Pioneers Society was the model they themselves had adopted True enough, Takano and the others had "tried as much as they could to incorporate this important principle" into the organization, but "besides the fact that the cooperative society system itself was already an absolutely revolutionary concept for Japan's laborers, people were also extremely distrustful of other people, so we were afraid that, if we adopted this principle, smooth running of the cooperative would be placed in jeopardy."

So, while they hoped that "once the majority of laborers came to recognize the benefits of this system... they would end sales on credit

\footnotetext{
2 Kiyoshi Ōshima and Kazuo Nimura, eds. and trans., "Takano Fusatarō," Meiji Nihon rōdō tsūshin-rōdō kumiai no tanjō [Meiji Japan labor communications: The birth of labor unions] (Iwanami Shoten, 1997), pp. 211-12.
}

${ }^{3}$ Ibid., pp. 193-95. 
and switch to cash purchases," in actual fact the cash purchase method was never adopted.

Thus even Fusatarō Takano, who tried so hard to introduce and establish in Japan a cooperative society formed by laborers, was forced to conclude, from sizing up the situation of consumer lifestyles in the Tokyo of that time, that the adoption of cash purchases in their co-op was not feasible. This goes to show the extent to which credit sales had taken firm root in the lives of urban dwellers at that time.

Next let us look at the situation in a regional industrial urban area that developed rapidly as the result of the location there of a governmentrun ironworks: the townships of Tobata and Yahata (both presently a part of the city of Kita-Kyūshū in Fukuoka Prefecture). According to materials from that period, ${ }^{4}$ most of the townspeople living in Tobata at the start of the twentieth century were factory laborers, many of them people who had moved into the area from other regions. The form of retail transaction involving daily necessities that was the norm there was sale on credit, with settlement dates usually set at every six months or one year, but in the case of sales of goods to laborers bills were being cleared away at twice-monthly intervals.

Thus in Tobata sale on credit formed the principal method of selling merchandise, despite the fact that the majority of the townspeople were laborers who had recently moved into the area, and who thus were not really suitable customers for sale-on-credit trade. It seems that in the case of sale on credit to the laborers, however, the danger of debts being reneged on was reduced by shortening the intervals between times of payment of the debts.

In the township of Yahata adjacent to Tobata, the sale-on-credit selling method was called into question because it was responsible for the raising of the selling prices of such merchandise. An administrative official from the government-run Yahata Ironworks, which held immense influence in the township, wrote in a newspaper article at the time that "the making of cash transactions the basic rule" was one of the important points to be considered in connection with improving commercial customs. ${ }^{5}$ The reason he gave was that, in a place like

\footnotetext{
${ }^{4}$ Kyūshū Tetsudō Kanrikyoku Eigyōka, Miteikō-ekisei ichiran, Kagoshima sen no ichi [Draft: Economic state of places with train stations, lines in Kagoshima] (1911), p. 117.

${ }^{5}$ Fukuoka nichinichi shimbun, 10 February 1906.
} 
Yahata, a newly developed area in which factory laborers made up the majority of the population, selling goods on a sale-on-credit basis was, generally speaking, a risky business, the collection of moneys owed was difficult, and retail merchants often incurred losses, so the retail merchants tended to charge higher prices for their merchandise in order to make up for such losses. He went on to say that the retail merchants were being asked to improve these conditions on their own initiative, and if they did not bring about any improvement the ironworks itself would be forced to respond by setting up a shop to supply daily necessities.

Thus in regard to the distribution of daily necessities, that even in newly established industrial urban centers in outlying regions the principal method of selling merchandise in the early twentieth century was sale on credit. Also, that in order to solve the problem of high prices in such regions people started thinking of the need for a switch in the method of sales, from sale on credit to cash transactions.

As the above cases show, the dominant method of selling daily necessities in Japan's urban retail trade at the end of the nineteenth century and the beginning of the twentieth century was that of goyokiki and sale on credit. This was not only because it was a method of sales convenient for the retail merchant, but also because, for the residents of the cities as well, it was a method that could help sustain their livelihood when they were temporarily short of income, and for these reasons the method continued to retain a firm grip in the community.

Still, as the case of Yahata shows, when, in keeping with the spread of industrialization, there was a steady influx of people into urban areas, the main problem connected with goyōkiki and sale on credit became all too clear. This problem, simply stated, was this: when sale on credit is engaged in with newly arrived customers whom the merchant does not know well, there is a higher risk of bad debt than when the merchant deals with customers he knows well, and this risk is covered by the prices of the merchandise, and so the prices of daily necessities go up. And it was against this background that the idea of changing the sales method that was used among retailers of daily necessities to cash transactions, with the customers taking the goods home themselves, came to be seized upon by urban administrators as an important policy goal. 
THE ESTABLISHMENT AND DEVELOPMENT OF MUNICIPAL MARKETS: THE CASE OF OSAKA

It was the establishment of municipal (retail) markets that was the greatest force in the spread of the cash purchase-carry home method of sales into the world of daily necessity retail trade. A municipal market is a market facility (as a rule, roofed over) that is constructed by a city administration (or that of a township, a district, or even a prefecture), in which private-sector retail merchants are allotted selling spaces, where they sell daily necessities, principally foodstuffs. The concept of city officials setting up a market for such a purpose, as it was then being put into effect in the West, especially in Germany, was first studied overseas, then introduced into Japan, by officials of the central government and such large cities as Tokyo, then by regional chambers of commerce and industry. ${ }^{6}$ A special feature of the Japanese municipal market, however, is that in some cases they strictly regulated the sales methods of the retail merchants who were actually engaged in sales activities in the market. To be more specific, in Japan's municipal markets the retail merchants were obliged to sell their merchandise for cash, with the merchandise price-tagged, and with a fixed price as the upper limit, and they were not allowed to deliver the goods. The city officials decided on the sales prices of goods by investigating the average wholesale prices of the various articles in sales in that city, adding on a margin of profit that they considered appropriate, and setting a retail price that was an upper limit; selling above that price was forbidden. Thus the retail merchants operating in the municipal market had their method of sales fairly restricted by the city officials, but this was done in order to promote some competition among the retailers. In a world in which goyokiki and sale on credit was the dominant method used by the retailers of daily necessities, leaving the sales method and the prices up to the retailers would not lead to a lowering of sales prices through competition among retail merchants; on the contrary, the chances were that they would avoid competition by corralling customers, then raise sales prices. This was why it was necessary to regulate the sales methods.

The first municipal market set up in Japan was in Osaka, in April 1918. In the first few years (1918-20) the city did not charge the mer-

${ }^{6}$ Harada, A Study of the History of Modern Japan's Markets, pp. 21-36. 
chants who set up shops in the municipal market any fees for renting space. As a result, the merchants in the municipal market enjoyed an advantage in running costs over general retailers who were paying rent for their places of business. Also, in the early days of the municipal market many of the merchants were wholesalers and brokers, and direct sales by producer groups were also carried out. This was an effort to eliminate the middlemen who intervened in the transactions of daily necessities and bring down the costs of distribution and thus lower the retail prices, but at the same time this also meant big losses to existing merchants. Still, most city dwellers at the time considered the merchants dealing in daily necessities as responsible for the steep rises in prices, and, bolstered by the voices of such city dwellers, city officials were able to proceed without fear of repercussions from merchants and give preferential treatment to those selling in the municipal market. ${ }^{7}$

Once into the 1920s, however, the alarming rises in the prices of goods started to head in the direction of stabilization, so the rationale for exempting sellers in the municipal market from paying fees for renting space was no longer valid, and rental fees began to be charged. Also, since it had become clear that, because of the enormous quantities of daily necessities that had to be distributed in the large cities of that time, elimination of middlemen was an unrealistic measure, and so it ended up that almost all the sellers appointed to operate in the municipal market were retail merchants. ${ }^{8}$ Also, at this time the retail merchants in the Osaka municipal market were formed into unions organized according to their type of business, and joint purchasing of merchandise was carried out. ${ }^{9}$ The latter, however, was limited, both in regard to the items purchased and in regard to the quantities purchased, so that the retail merchants operating in the municipal market did not gain the overall benefits of large-volume purchasing. Thus the sellers operating in the municipal market in the 1920s did not enjoy a particularly advantageous position over the general retail merchants, either in operating costs or in purchases.

${ }^{7}$ Ibid., pp. 118-24.

${ }^{8}$ Ibid., pp. 125-29.

9 Makoto Hirota, "Kōsetsu shijō to nichiyōhin kouri shōgyō no kindaika-Ōsaka-shi ojirei to shite" [Municipal markets and the modernization of daily necessity retail trade: The case of Osaka], Osaka Daigaku keizaigaku 36/1-2 (Sept. 1986), pp. 321-22. 
Table 1. Trends in the Development of Osaka City's Municipal Retail Markets

\begin{tabular}{cccccc} 
Year & $\begin{array}{c}\text { Number of } \\
\text { Markets }\end{array}$ & $\begin{array}{c}\text { Gross } \\
\text { Sales* }^{*}\end{array}$ & $\begin{array}{c}\text { Sales per } \\
\text { Market }\end{array}$ & Period & $\begin{array}{c}\text { Number of } \\
\text { New Markets }\end{array}$ \\
\hline 1918 & 4 & 2,135 & 523 & & \\
1920 & 10 & 11,892 & 1,189 & $1918-20$ & 6 \\
1925 & 41 & 31,178 & 709 & $1920-25$ & 31 \\
1930 & 52 & 31,274 & 579 & $1925-30$ & 11 \\
1935 & 54 & 22,990 & 411 & $1930-35$ & 2
\end{tabular}

*Unit: $¥ 1,000$

Source: Hirota, Municipal Markets and the Modernization of Daily Necessity Retail Trade, p. 315.

This fact notwithstanding, city officials continued to build more municipal markets during the period 1920-25 (see Table 1). In addition, private retail markets (private markets), imitating the management techniques and sales methods of municipal markets, also increased at a rapid pace. ${ }^{10}$ The fact that both municipal and private retail markets developed at this time despite the loss of any advantages in running costs or the purchasing of goods was an indication of the extent to which they were welcomed by city dwellers as retail facilities in the vanguard of latest developments, because of the way they supplied daily necessities at moderate prices by concentrating on the cash-purchase, take-home format of selling merchandise. ${ }^{11}$ In

${ }^{10}$ In 1920 there were 27 private retail markets within the city of Osaka; by 1925 these had increased to 81 . Ibid., p. 323.

${ }^{11}$ Another reason for the spread of private retail markets in the city of Osaka was the fact that the great majority of rented residences in the city were of the row-house type (see Makoto Terauchi, Ōsaka no nagaya -kindai ni okeru toshi to jükyo [Row houses in Osaka: Cities and residences in the modern age] (INAX,1992), p. 8). Most residential land in Osaka City in the 1920s was built up methodically as land managed by private-sector land readjustment partnerships and land companies, on the basis of the Urban Planning Act and the Land Readjustment Act passed in 1919. The residences on this land were built in relatively orderly fashion as two-story row houses for use as rental dwellings by the landlords. Most of the private retail markets were built by the same landlords or land companies as row houses that could serve as dwellings and shops, in order to meet the demands of the residential neighborhood thus located. Shop nagaya that also served at the same time as dwellings were built along both sides of a lane or passageway, and all that had to be done to make a marketplace was to put up a sunscreen or awning over the lane/passageway and that was enough to turn the place into a market (see Ōsaka Chiiki Shinkō Chōsakai, comp., Ōsaka no kourigyō to shōtengai-sono kako, genzai, mirai [Osaka's retail trade and shopping areas: Their past, present, and future] (Kansai Jānaru Sha, 
the case of Osaka City, the takings per shop among perishable food retailers in the municipal markets were approximately three times that of the general retailers. ${ }^{12}$ In the same city even big department stores like Mitsukoshi and Daimaru set up retail markets within their premises and attempted to make inroads into the area of daily necessities retailing. ${ }^{13}$ Also, it was commonly said that, when a municipal market was established in an area of the suburbs of Osaka City in which population numbers were still low, it was sure to lead to an increase in the population of that area and the formation of private retail markets and shopping areas. ${ }^{14}$ Documents related to the establishment of retail markets in that period also state that "once retail markets and bathhouses were built in an area, that area would develop. And in fact, wherever a retail market was put up and a bathhouse was built, residences mushroomed in that neighborhood, the area developed rapidly, and land prices jumped. Having become the most attractive of prospects for investors, private retail markets were set up one after the other." 15

At the beginning of the 1930s the municipal markets in Osaka reached their peak in terms of quantity (number of markets, gross sales, and sales per market). After this the pace of establishing municipal markets fell (see Table 1). The reason for this was that, since municipal markets were business ventures funded by taxes collected from the public, they were easily open to political pressure (especially from retail traders, who themselves were also taxpayers). At this time of the Great Depression, when many retail traders were finding it difficult to make a living, further establishment of the municipal markets that

1985), p. 29). As an example of a private retail market constructed on the initiative of a land company we have the Jōtō Market built by the Settsu Land Company in the village of Jōtō in Higashinari-gun in 1916 (see Ōsaka-fu Jichi Kōkyūkai Jōtō-gun Shibu, Higashinarigun shi-jōkan [Records of Higashinari-gun, volume 1] (1925), pp. 809-10).

12 Makoto Hirota, "Kōgyōka to nichiyōhin shijō, Taishō-ki-Kōbe-shi no baai" [Industrialization and daily necessity markets: Taishō Period, the case of Kobe], Ōsaka Daigaku keizaigaku 37/4 March 1988): 34.

13Shin'ya Hashizume, Nigiwai o tsukuru—kindai Nihon no kükan purannātachi [Creating bustling business: Modern Japan's space planners] (JDC, 1995), pp. 72-74.

${ }^{14}$ Hirota, Municipal Markets and the Modernization of Daily Necessity Retail Trade, pp. 323-24.

${ }^{15}$ Hirota, "Industrialization and daily necessity markets," p. 37. 
were adding to their miseries was not permissible. ${ }^{16}$ At the same time, however, private retail markets, which had been stimulated by the appearance of the municipal ones and had developed alongside the latter, were being newly built in quick succession, and they complemented the latter in quantitative aspects. ${ }^{17}$

\section{SLUGGISHNESS IN THE MUNICIPAL MARKETS IN THE CAPITAL, TOKYO}

In contrast with the quantitative and qualitative achievements of the Osaka municipal markets, the status of municipal markets in the capital, Tokyo, was quite low. In 1932 the percentage of the city's retail sales totals taken in by the retail markets was $14 \%$ for white rice, $20.8 \%$ for fruit and vegetables, and $20.2 \%$ for seafood. ${ }^{18}$ In Osaka, on the other hand, the figures for the same items in 1935 were a low $7.5 \%$ for white rice but a high $47.9 \%$ for fruit and vegetables and a higher $74.6 \%$ for seafood. ${ }^{19}$ Thus the retail markets in Osaka could boast of an overwhelming dominance in the retail sale of perishable foods.

After the rice riots of the summer of 1918, municipal markets had been set up in one city after another throughout the country as a measure to cope with the steep rise in prices in the cities. But even though the concept of setting up municipal markets had surfaced in the city of Tokyo earlier than in the city of Osaka, ${ }^{20}$ turning the concept into concrete reality took much longer in Tokyo than in Osaka. Furthermore, in all of the five other major cities (i.e., Yokohama, Nagoya, Kyoto, Osaka, and Kobe) the main force behind the establishment and operation of the municipal markets was the city administration. Only in Tokyo was the city government unable to participate directly in municipal markets when they were first started; instead, they had

${ }^{16}$ Takemasa Ishihara, Kösetsu kouri shijō no seisei to tenkai [Formation and evolution of municipal retail markets] (Chikura Shobō, 1989), p. 129.

${ }^{17}$ From the 81 private retail markets existing within the city of Osaka in 1925 the numbers rose to 110 in 1930, and to 151 in 1935 (see Hirota, Municipal Markets and the Modermization of Daily Necessity Retail Trade, p. 323).

${ }^{18}$ See Ishihara, Formation and Evolution of Municipal Retail Markets, p. 131 for the totals of retail markets set up by the city, the prefecture, and private business.

${ }^{19}$ Ibid., where total figures are given for municipal and private retail markets.

${ }^{20}$ Ibid., p. 14. 
Table 2. Percentages of Sales, by Types of Goods, in Municipal Markets in the 6 Major Cities (1937)

\begin{tabular}{llllllr} 
& $\begin{array}{l}\text { Cereal } \\
\text { Grains }\end{array}$ & $\begin{array}{l}\text { Fruits and } \\
\text { Vegetables Seafood }\end{array}$ & $\begin{array}{c}\text { Meat } \\
\text { and Eggs }\end{array}$ & $\begin{array}{l}\text { Other } \\
\text { Foods }\end{array}$ & $\begin{array}{l}\text { Nonfood } \\
\text { Items }\end{array}$ \\
\hline Tokyo & $32.0 \%$ & $10.7 \%$ & $15.6 \%$ & $6.4 \%$ & $20.0 \%$ & $15.3 \%$ \\
Yokohama & $33.3 \%$ & $14.4 \%$ & $12.5 \%$ & $6.8 \%$ & $15.2 \%$ & $17.8 \%$ \\
Nagoya & $21.4 \%$ & $12.4 \%$ & $17.4 \%$ & $9.6 \%$ & $22.9 \%$ & $16.3 \%$ \\
Kyoto & $17.4 \%$ & $12.9 \%$ & $18.8 \%$ & $10.4 \%$ & $33.7 \%$ & $6.8 \%$ \\
Osaka & $12.9 \%$ & $11.0 \%$ & $15.9 \%$ & $7.6 \%$ & $27.8 \%$ & $25.8 \%$ \\
Kobe & $11.2 \%$ & $19.8 \%$ & $16.1 \%$ & $14.4 \%$ & $21.8 \%$ & $16.7 \%$
\end{tabular}

Source: Takemasa Ishihara, Formation and Evolution of Municipal Retail Markets, p. 134. Note that figures for Osaka total $101 \%$ in the original data.

to entrust their establishment and operation to a foundation-type body called the Tōkyō Nichiyōhin Shijō Kyōkai [Tokyo Daily Necessities Market Association], to which the Tokyo government gave its backing. ${ }^{21}$

Another special characteristic of the municipal markets in Tokyo was the fact that their sales of rice wee a consistently high percentage of their gross sales (see Table 2). Of course, in general the takings from the sale of rice represented a high percentage of gross sales in all the early municipal markets, including the ones in Osaka, ${ }^{22}$ the reason being that the early municipal markets had as their major objective an easing of the social unrest brought about by the soaring prices of rice during and immediately after World War I by providing rice, the staple food, at a low price (not infrequently even supplying the rice at lower than cost prices). But afterwards the municipal markets in Osaka City expanded the number of different items it handled; while they continued to deal principally in perishable foods, they also started selling a diversity of goods that even included dry goods and everyday sundries, thus increasing their impact on the consumption patterns of city dwellers. The municipal markets in Kyoto, Kobe, and Nagoya followed a similar trend. Those in Tokyo, however, were unable to break away from the main objective for which they were instituted until much later, and consequently rice sales remained a high percentage of their takings. As a result, their impact on the consumption patterns of Tokyo dwellers was limited.

${ }^{21}$ Ibid., pp. 64-69.

${ }^{22}$ The percentages of rice sales in 1919 were $56.4 \%$ in Tokyo, $75.8 \%$ in Nagoya, and $43.7 \%$ in Osaka. Ibid., p. 136. 
THE IMPACT OF MUNICIPAL MARKETS ON RETAIL TRADE IN DAILY NECESSITIES: THE SPREAD OF CASH SALES

Perhaps the best indication of the impact the establishment and spread of municipal markets had on retail trade in daily necessities in the cities can be found in the degree to which cash sales in that retail trade spread. Table 3 shows the percentage of shops in Tokyo City, Osaka City, and Osaka Prefecture in which the percentage of cash sales (a value that shows what percent of each retail shop's turnover consisted of cash sales) was $80 \%$ or more, as well as those in which the percentage was $50 \%$ or more, in different categories of the principal daily necessities. The first thing that can be clearly seen from the table is that in Tokyo at this time cash sale was not the generally accepted sales method in retail trade of daily necessities. If we look at the different items handled, we can find several differences in the percentages of cash sales between white rice, alcoholic beverages, and fuel (firewood, charcoal) and fruits \& vegetables and seafood, but the retail shops whose cash sales were $80 \%$ or more of their takings came to under $20 \%$ of all retail shops in regard to perishable foods, and no more than approximately $10 \%$ in regard to other categories.

In Osaka City, where municipal and private retail markets were the most developed in the whole country, we find that the percentage of adoption of cash sales in the retail trade handling daily necessities was quite different for the same period. In the shops in which $80 \%$

Table 3. Percentages of Cash Sales in Daily Necessities Retail Shops in Tokyo City, Osaka City, and Osaka Prefecture

\begin{tabular}{lccc|ccc}
\hline & \multicolumn{3}{c}{ Shops with Cash Sales of $80 \%$ or More } & \multicolumn{3}{c}{ Shops with Cash Sales of $50 \%$ or More } \\
& Tokyo City & Osaka City & Osaka Pref. & Tokyo City & Osaka City & Osaka Pref. \\
\hline Vegs./fruits & $15.31 \%$ & $80.76 \%$ & $37.0 \%$ & $38.17 \%$ & $94.51 \%$ & $70.4 \%$ \\
Seafood/seaweed & $12.58 \%$ & $75.33 \%$ & $30.3 \%$ & $35.44 \%$ & $88.52 \%$ & $59.6 \%$ \\
Drinks/seasonings & $9.84 \%$ & $29.93 \%$ & $19.2 \%$ & $37.67 \%$ & $50.27 \%$ & $44.8 \%$ \\
Cereal grains/flours & $7.72 \%$ & $21.0 \%$ & $12.5 \%$ & $40.03 \%$ & $37.27 \%$ & $31.5 \%$ \\
Fuels & $7.88 \%$ & $27.64 \%$ & $18.6 \%$ & $34.26 \%$ & $44.83 \%$ & $40.3 \%$ \\
\hline
\end{tabular}

Sources: Osaka Prefecture, Ōsaka-fu shōgyō chōsa sho [Survey of commerce in Osaka Prefecture] (1935), pp. 540-41; Osaka City Offices, Ösaka-shi shōgyō chōsa sho [Survey of commerce in Osaka City] (1937), pp. 540-41; Tokyo City Offices, Tökyōshi shōgyō chōsa sho [Survey of commerce in Tokyo City] (1933), pp. 546-47. 
or more of their takings were in cash sales, about $80 \%$ of their vegetables and fruits were sold by cash, and nearly $80 \%$ of their trade in seafood and seaweed. In terms of the amount of money involved, of the $12,731,666$ yen in total sales for vegetables and fruits, 10,841,897 yen, or $85.16 \%$, was in cash sales. ${ }^{23}$ Similarly, of the $12,061,553$ yen in total sales for seafood and seaweed, $9,874,803$ yen, or $81.87 \%$, was in cash sales. In other words, in Osaka City at this time the selling of perishable foods for cash was practically the universally accepted thing. This was in stark contrast with the situation in the city of Tokyo. When we look at other categories of daily necessities, too, we find that, in the retail shops where cash sales made up $80 \%$ or more of their total sales, $21.0 \%$ of the sales of cereal grains and flours were in cash, $29.93 \%$ of the sales of alcoholic beverages, seasonings, and cooling drinks, and $27.64 \%$ of the sales of fuels. ${ }^{24}$ In the areas in which the municipal markets had only a small share of the total sales within the city (e.g., $7.5 \%$ in white rice), the rate of adoption of cash sale was low in comparison with perishable foods.

When we look at the rate of adoption of cash sales in retail trade in daily necessities in Osaka Prefecture (for all areas except Osaka City) at approximately the same time, we find that the rate of adoption of cash sales tends, like Osaka City's, to be high in the area of perishable foods, but low in the areas of cereal grains and flours, drinks and seasoning, and fuels. Overall, the rate of cash sales was low in comparison with Osaka City's.

Thus we find there was a large difference between Tokyo City and Osaka City in the spread of cash sales in the retailing of daily necessities around 1935. When we compare Osaka City with the rest of Osaka Prefecture, too, we find that cash sales were clearly a more widespread practice in the former than in the latter. This might give the impression that cash sales in the retailing of daily necessities naturally become more common as urbanization progresses. Yet if we compare Osaka Prefecture with Tokyo City, we see that the former (remember, in the figures given above it does not include Osaka City), a very rural area, has a higher cash-sale adoption rate than Tokyo City, which not only was a huge city at the time but also the capital of the

${ }^{23}$ Osaka City Offices, Ōsaka-shi shōgyō chōsa sho [Survey of commerce in Osaka City] (1937), p. 105.

${ }^{24}$ Ibid., pp. 105-108. 
country. And even in Osaka City, where the spread of cash sales was so conspicuous, the rates of cash sales for categories of items like cereal grains and flours, drinks and seasonings, and fuels (areas in which municipal markets held a very low share of the markets) were under $30 \%$ even in those shops where $80 \%$ or more of their sales were in cash. In these areas the position of goyökiki and sale-on-credit selling remained as high as ever (but still not as high as in Tokyo City). From all these results it can be seen that cash sales in the retailing of daily necessities do not become widespread as a natural result of progress in urbanization, but they are due to a large extent to such human efforts (policies) as municipal markets.

\section{IN CONCLUSION}

What we have seen above is that, in Japan at the turn of the century, there was an increase in urban populations as industrialization advanced, and along with this increase came soaring prices for materials that city dwellers needed for their daily lives. Attention was drawn to the sales methods used in the retail trade dealing in daily necessities-goyökiki and sale on credit-as a contributing factors to those price rises. Still, it was not an easy thing for the general retail trader, used to the goyökiki and sale-on-credit selling method, to adopt the cash-purchase, take-home method. For a retailer setting a higher value on the stability of his own livelihood than on the development of his business, voluntarily switching over to cash selling was a rare event. 25 .

${ }^{25}$ One more reason for retailers sticking with the sale-on-credit approach is that buying on credit from retail traders was found to be a very convenient way for city dwellers to make up shortages in their budgets. According to a Tokyo City Offices report, "Doboku kenchiku rōdōsha to hiyatoi rōdōsha" [Civil engineering and construction laborers and day laborers], Tökyō-shi Shakaikyoku jihō (July 1933), p. 70, the following were the most common ways in which such construction and day laborers tried to supplement shortages in money available for daily living. In first place for construction laborers was using money that they should have used to pay house rent, room rent, or land rent (38\%); second was borrowing money $(21 \%)$; third was buying on credit (13\%); fourth was pawning possessions $(10 \%)$; and fifth was borrowing from relatives or friends $(9 \%)$. For the day laborers, on the other hand, buying on credit only ranked in sixth place, at $4 \%$.

According to a report of the Osaka City Social Department Labor Section, "Ōsakashi shitsugyōsha jōtai chōsa" [Survey of the situation of the unemployed in Osaka City], Ösaka-shi Shakaibu hōkoku (no. 170), pp. 14-15, buying on credit ranked fourth, at $10.4 \%$, 
What was effective to a great extent in changing this attitude of retailers was the municipal market. In Osaka City the city government took the initiative and worked hard to set up municipal markets and make them meaningful places of business, and showed that customers would flock to them. By seeing what happened and how things worked out, the general retail merchants experienced firsthand, rather than by arguments, the power of such places to attract customers, and the number of retailers desirous of becoming tenants of such retail markets increased. Responding to this general trend, more and more people constructed retail markets and called for tenants. The result of all this was that the percentage of cash sales in the daily necessities retail trade, especially in the perishable foods area, became extremely high.

In Tokyo City, however, which had been late in getting started with municipal markets, the retail merchants were unable to feel confident in the future of the retail market, with the result that, in that city, the development of the retail market and the adoption of cash sales of daily necessities lagged far behind their counterparts in Osaka City. And this also had a great influence, I believe, on why the continued low-key existence of the municipal market in the capital, Tokyo, has for so long not attracted the attention of historians to the role of the municipal market.

after not paying their rents $(26.2 \%)$, borrowing money $(23.0 \%)$, and borrowing from friends or relatives $(17.6 \%)$, but ahead of drawing on savings, cashing insurance policies, or getting money from a mutual aid association (10.1\%) and pawning possessions $(7.2 \%)$.

Thus even in Osaka City, where the use of cash sales was so widespread, and even among those people who you would expect, because of the relative instability of their incomes, would find it difficult to become customers of retail merchants offering sales on credit, such as construction laborers, day laborers, and the unemployed, the use of sale on credit to overcome a shortage of living expenses was being used as before. 